\title{
The Implicature Theory: a Case Study
}

\author{
RODRIGO JUNGMANN \\ Universidade Federal de Sergipe
}

\begin{abstract}
Several attempts have been made by direct reference theorists to accommodate the intuitive datum of referential opacity - the failure of co-referential proper names to substitute salva veritate for one another within the embedded 'that'-clauses of attitude ascription sentences. The theory advocated by Nathan Salmon in his 1986 book Frege's Puzzle is probably the best worked out version of what is referred to below as 'The Implicature Theory'. Salmon claims that referential opacity is an illusion brought about by our failure to distinguish the semantic content of attitude ascriptions from their 'pragmatic impartations', as Salmon calls them. Regrettably, his work leaves it entirely mysterious how the relevant pragmatic impartations are routinely conveyed. Salmon vaguely suggests that Gricean conversational implicatures are involved. My central claim in this paper is that Salmon is mistaken, since the pragmatic impartations required by his theory do not satisfy the criterion of cancelability, which is met whenever a genuine conversational implicature occurs. The argument in question is, to the best of my knowledge, original with me.
\end{abstract}

Keywords: Cancelability, conversational implicatures, implicature theory, propositional attitudes.

It is not at all hard to come up with sentence pairs which differ solely in that they contain different co-referring names within a 'that'- clause, preceded by any of the propositional attitude verbs. Let one such pair be

(1) John believes that George Orwell was a great writer.

(2) John believes that Eric Arthur Blair was a great writer.

It is a fact of literary history that 'George Orwell' was a pseudonym used by Eric Arthur Blair. It is not inconceivable, though, that, even now, John might be entirely unaware of this fact. Let us suppose that John is a fervent admirer of Orwell's novels, but goes on not knowing that the names 'George Orwell' and 'Eric Arthur Blair' refer to the same individual. In that case, we might take sentence (1) to express a true proposition. But, given John's ignorance of the fact that George Orwell was Eric Arthur Blair, he might fail to believe that Eric Arthur Blair was a great writer. The latter situation could come about in a number of ways. For instance, John could fail to believe that Eric Arthur Blair was a great writer, simply because he never heard

Principia 13(3): 405-419 (2010).

Published by NEL — Epistemology and Logic Research Group, Federal University of Santa Catarina (UFSC), Brazil. 
the name 'Eric Arthur Blair' in his entire life or because, though having been exposed to the name in some context or other, maybe by having at some point actually met a man by the name of 'Eric Arthur Blair', he did not know then that Eric Arthur Blair was a writer at all and so could hardly be said to have believed that Eric Arthur Blair was a great writer. Alternatively, he might have known that his next-door neighbor, Eric Arthur Blair, was in fact a writer, but have formed no opinion as to the quality of his work. And one might easily envisage a scenario in which John, as it were, actively disbelieves that Eric Arthur Blair was a great writer, say, as a result of having read a terrible poem authored by Blair. In all such cases, and, perhaps, most clearly of all in the last one considered, there would seem to be compelling intuitive grounds for taking sentence (2) to express a false proposition, in most contexts of utterance. This point can, of course, be made more perspicuous by an appeal to a recurring sentence pair in the literature on propositional attitude ascriptions:

(3) Lois Lane believes that Superman can fly.

(4) Lois Lane believes that Clark Kent can fly.

In the context of the Superman legend, it is plain that Lois Lane believes that Superman can fly. At the same time, we are naturally led to say that she does not believe that Clark Kent can fly. It sounds decidedly counterintuitive to suggest that she does. But if all there was to the meaning of proper name was its referent we should expect sentences (3) and (4) to express the very same proposition. At first sight, this seems to be out of the question. After all, it would be generally agreed that the propositions expressed do not even have the same truth values.

Now, some direct-reference theorists, who have rejected Fregean sense altogether, have risen up to the challenge posed by a consideration of the sort of problems that led Frege to introduce the notion in the first place, while trying to remain, in varying degrees, as faithful as possible to their direct-reference commitments.

\section{II}

As regards what is normally taken to be the failure of proper names to substitute for one another salva veritate within 'that'-clauses embedded in attitude ascriptions, direct reference philosophers have taken more or less radical stances. One particularly radical stance is to be found in the theory presented by Nathan Salmon in his Frege's Puzzle.

According to Salmon, the sentences in such pairs as (1) and (2) or (3) and (4), contrary to appearances, do encode the very same propositions and share the same truth-values. Since it is true to say that 'John believes that George Orwell was a great writer', it follows that it is just as true to say that 'John believes that Eric Arthur Blair

Principia 14(3): 405-419 (2010). 
was a great writer', in all the envisaged scenarios. Analogously, since we can be certain of the truth of 'Lois Lane believes that Superman can fly', it follows that the sentence 'Lois Lane believes that Clark Kent can fly' also encodes a true proposition.

Salmon's general take on belief ascriptions follows naturally from his distinctive views on the nature of simpler propositions where no ascriptions are present. On the convenient pretence that the Superman legend is true, let us pause to consider the sentences below, which are respectively embedded in (3) and (4):

(5) Superman can fly.

(6) Clark Kent can fly.

For Salmon, declarative sentences have as their primary purpose to encode pieces of information, which he takes to be the propositions encoded by the sentences. According to what he has termed the "Modified Naïve Theory", the information content encoded by a complex sentence is made up of the information contents of its component parts. What any given proper name-a simple singular term, as Salmon puts it - contributes to the information content encoded by a sentence in which it occurs is just its referent. Now, if we refer back to sentences (5) and (6), we find that they have identical predicates and that the different proper names occurring in them have, as is known, one and the same referent. On Salmon's view, then, sentences (5) and (6) are bound to encode the same piece of information, which is to say that they encode the same proposition.

Admittedly, there is something appealing in Salmon's construal of propositions in terms of their information content, as defined by his theory. For sentences (5) and (6) seem to be saying the same thing about-by attributing the same property to-the one individual, who is the referent of both 'Superman' and 'Clark Kent', and, to be thus portraying the same state of affairs. Of course, the well-known Fregean objection to this view on the individuation of propositions is based on the realization that sentences (5) and (6) appear to express propositions with distinct cognitive values, because someone might know, believe, suspect, etc. that either of them is true, without thereby being compelled to harbor the same attitude to the other proposition. I will later have occasion to stress that such concerns should be seen as forming a continuum with those that come up in the study of attitude ascriptions.

In any event, since for Salmon, sentences (5) and (6) encode the same proposition, made up solely of the individual who is the referent of both 'Superman' and 'Clark Kent' and of the property 'being able to fly', sentences (3) and (4), by virtue of placing Lois Lane in the 'believes-that' relation to what turns out to be the same proposition, are themselves bound to encode the same true proposition, appearances to the contrary notwithstanding.

Principia 14(3): 405-419 (2010). 
Salmon acknowledges that his position involves a substantial departure from the characteristic ways in which ordinary people, operating at a pre-theoretical level of semantic awareness, go about the business of judging the truth values of attitude ascriptions in general-and belief-reports, in particular-and that some account must be offered as an explanation of just what it is that leads people astray and make them wrongly, to his mind, take sentences (2) and (4) to express falsehoods.

His general strategy consists in maintaining that, in light of the considerations presented above, sentences like 'Lois Lane believes that Clark Kent can fly' and, 'John believes that Eric Arthur Blair was a great writer', as used in the setting described , do indeed encode the same true propositions as sentences (1) and (3) respectively, with our natural inclination to say that they do not being accounted for by our failure to notice the difference between what is strictly and literally the information encoded by utterances of (2) and (4) and the pragmatically imparted information which is a typical by-product of such utterances. Thus, the proposition encoded by 'Lois Lane believes that Clark Kent can fly', though strictly true-since the proposition encoded by (1) is-is naturally taken to be false, because it misleadingly imparts the information that Lois Lane would give her assent to the sentence 'Clark Kent can fly', which, unbeknownst to her, encodes the same proposition as the sentence 'Superman can fly'.

An appeal to the difference between the proposition $p$ actually expressed by a speaker's utterance of a sentence $S$ and some additional proposition $q$, which, in spite of being in no way a part of the semantic content of $p$ or even entailed by $p$, may be imparted or implicated by the speaker's utterance of $S$ is, of course, not original with Salmon. Paul Grice's theory of conversational implicature offers a fairly detailed account - one that is still being actively expanded and, to some extent, revised by current research - of the mechanisms to be held responsible for the fact that speakers are routinely capable of conveying a great deal more information by means of their everyday utterances than what can be accounted for solely by a consideration of the conventional linguistic meaning of the sentences uttered.

Since in order to account for the apparent failure of co-referring names to be intersubstitutable salva veritate in attitude ascription contexts, Salmon explicitly avails himself of the distinction between information that is semantically encoded and information that is pragmatically implicated (or imparted, in his own phraseology), it seems fair to characterize his theory, as Recanati (1993) does, as being an instance of what the latter calls 'The Implicature Theory' of belief-reports, a blanket term intended to cover all attempts to explain apparent failure of substitutivity by recourse to the semantics/pragmatics distinction.

\section{III}

Philosophers who favor or, at some point, favored-and offered more or less ex-

Principia 14(3): 405-419 (2010). 
plicit statements of - the Implicature Theory include, in addition to Salmon himself, Urmson (1968), Barwise and Perry (1981, 1983), McKay (1981), Soames (1987), among others. Interestingly, Salmon, for all the formidable technical fastidiousness of so many passages of Frege's Puzzle, neglects to explore in any significant detail the nature of the mechanisms underlying the generation of the pragmatic impartations so badly required by his theory. Worse still, he leaves it somewhat unclear (p.85) how his own notion of pragmatically imparted information is related to Grice's work.

\section{IV}

It does not take a lot of philosophical acumen to appreciate the fact, already hinted at above, that the amount of information speakers are capable of conveying in the course of taking part in communicative exchanges is not exhausted by, and, very often, far surpasses, the information that may be said to be directly encoded by what is strictly and literally said. ${ }^{1}$ The importance of Grice's contribution resides in the fact that he provided the study of the mechanisms underlying the generation of these familiar linguistic phenomena with a sound theoretical foundation, by systematically relating them to principles which it is reasonable to see as forming a crucial aspect of our communicative practices in so far as these practices tacitly rely on the assumption that the parties involved are required to interact in a relevantly co-operative way in order to communicate successfully. Thus, the principles Grice had in mind are to be regarded as the unspoken rules people may be normally expected to adhere to with some fair degree of consistency in order that communication may serve some shared set of purposes.

Presented below is a list comprising Grice's all-encompassing Cooperative Principle and the four maxims of conversation it subsumes. The content of all but one of the maxims is given by a corresponding set of submaxims.

The Cooperative Principle

Make your conversational contribution such as is required, at the stage at which it occurs, by the accepted purpose or direction of the talk exchange in which you are engaged.

The maxim of Quantity

(i) Make your contributution as informative as is required (for the current purposes of the exchange).

(ii) Do not make your contribution more informative than is required.

The maxim of Quality

(i) Do not say what you believe to be false.

(ii) Do not say that for which you lack adequate evidence.

Principia 14(3): 405-419 (2010). 
The maxim of Relevance

Make your contribution relevant

The maxim of Manner

(i) Avoid obscurity of expression.

(ii) Avoid ambiguity.

(iii) Be brief (avoid unnecessary prolixity)

(iv) Be orderly. ${ }^{2}$

Short though it is, the above list of principles has a distinguished track record in linguistics and the philosophy of language, as it has been credited with an importance that far outstrips the immediate role the principles play in the generation of implicatures.

Now, different criteria may be invoked in the classification of conversational implicatures. For present purposes, we need to look at the so-called 'particularized' conversational implicatures involving particular contexts of utterance. As an example of the latter sort of implicature, Grice asks us to consider the exchange between A, a person standing by an immobilized car, and B, a passer-by:

\section{A: I've run out of gas.}

B: There's a gas station around the corner.

Since one may normally presume that B's utterance would be responsive to A's concerns, rather than wantonly gratuitous, A can take B to have implicated that, as far as he knows, the gas station in question is open and has gas to sell, as B's utterance would otherwise be entirely irrelevant. Clearly, the utterance made by B might carry an indefinite number of entirely different implicatures in suitably modified contexts.

If, say, A had stopped his car by the curb and said to some passer-by 'I am looking for an Italian restaurant. It's supposed to be across the street from a gas station', B would have implicated that there is a chance that the A might find the restaurant he is looking for by going around the corner.

The implicatures required by the Implicature Theory to account for opacity can be safely presumed to be of the second sort. For even in the case of ascriptions like 'Lois Lane believes that Clark Kent can fly', theorists may, with sufficient ingenuity, come up with scenarios in which it is clear to the addressee(s) of (4) that there is not the slightest suggestion that the ascriber intends to be faithful to something like the contents of Lois's beliefs.

Now, if one looks for what is common to the implicatures generated by B's utterance in both the situation envisaged by Grice and in the modified setting offered here, one immediately notices that both come about as a result of the assumption that $\mathrm{B}$ meant his utterance to be relevant to the communicative context he found

Principia 14(3): 405-419 (2010). 
himself in. B specifically observed the maxim of Relevance. Since he did not fail to observe any of the other maxims, we may credit him with having been fully cooperative. As noted by Levinson (1983), implicatures of this sort are now referred to as standard implicatures, even though this term is not Grice's.

This leaves us with a second criterion we can appeal to in categorizing implicatures. For, in contrast to standard implicatures, some implicatures are generated in circumstances in which a speaker is clearly failing to observe one or more of the maxims. As Grice put it, a speaker may flout the maxims. In cases exhibiting what Grice called floutings or exploitations, the implicature goes through as a result of the addressee(s) assuming that the speaker still intended to be co-operative at some deeper level, and thus to abide by the Cooperative Principle, broadly construed. ${ }^{3}$ In one of Grice's examples of floutings, a professor is asked by a former student, now looking for a job as a philosophy instructor, to write a letter of recommendation on his behalf. The professor's letter reads simply: 'Dear Sir, Mr. X's command of English is excellent, and his attendance at tutorials has been regular. Yours, etc'. This represents a blatant violation of the first submaxim of quantity: 'Make your contribution as informative as is required'. Yet, the addressee(s) of the letter may still see the professor's letter as being, at bottom, co-operative. If the professor had decided to be altogether uncooperative, he might have opted out of the Cooperative Principle by simply refusing to write the letter. If he did bother to writer the letter, it may be assumed that he wanted the letter to impart information that he is unwilling or reluctant to state directly. In the case at hand, the natural conclusion to draw is that the professor implicated that his former student is no good at philosophy.

As we will see shortly, some Implicature Theorists have produced an analogue of Grice's principles by thinking up maxims - intended to address the peculiarities of the case involving attitude ascriptions-which may specify some of the communicative obligations incurred by those ascribing propositional attitudes to others. And just as in the cases considered by Grice, implicatures are supposed to go through with either full or partial compliance with the maxims.

Before looking at what these theorists have achieved, we should complete our brief sketch of Grice's theory of conversational implicature by having a look at what he regarded as some of the distinguishing features of implicatures. The features listed by Grice are supposed to be always (or nearly always) present whenever one is dealing with a genuine conversational implicature. As noted by Grice, implicatures are cancelable, calculable, non-detachable, non-conventional and indeterminate. ${ }^{4}$

Concerning the last three features, I will have nothing to say, because they have, as far as I can see, no bearing on my presentation. Most importantly for present purposes, implicatures exhibit the characteristics of cancelability and calculability. As regards the former, one may note that, in contrast to the case of logical entailments, a speaker may utter a sentence which, as he realizes, may be taken to have carried 
a certain implicature, and go on to deny, without contradiction, that he ever meant to imply it. Thus, in the course of a conversation about the current philosophical scene, someone might say 'Kripke hasn't published anything over the last decade or so'-which might be taken to implicate that the speaker finds fault with Kripke's low output in recent years-and go on to add 'I don't mean to imply that this is bad. Actually, I have always admired him for placing quality over quantity'. This example shows how implicatures can be explicitly canceled. Significantly, they can also be contextually cancelable. The latter situation arises whenever some aspect of the context of utterance simply prevents the audience from taking a particular implicature to have been part of what the speaker intended to communicate. Thus, while an utterance of a sentence like 'Jim is on his way to becoming a millionaire', would normally implicate that Jim is already very rich, the implicature would not be present at all if the sentence was part of a jocular exchange among people who, having heard that their acquaintance Jim got a pay raise, are intent on making fun of what they see as Jim's delusions of grandeur.

The significance of calculability rests on the fact that for every putative conversational implicature it should be possible for the hearers to construct an argument justifying why, on the assumption that the speaker is fully observing the maxims or, in the case of floutings, at least the Cooperative Principle, they take the implicature in question to have been generated. Thus, the person who hears the sentence 'There's a gas station around the corner' as a reply to 'I am looking for an Italian restaurant. It's supposed to be across the street from a gas station' could reason as follows:

He has said that there is a gas station around the corner; there is no reason to suppose that he is not observing the maxims and, specifically, the maxim of Relevance. He could not be doing this unless he thought that there is a chance that I might find the Italian restaurant by going around the corner; he knows (and knows that I know that he knows) that the supposition that he thinks that I might find the Italian restaurant by going around the corner is required; he has done nothing to stop me thinking that I might find the Italian restaurant by going around the corner; he intends me to think, or is at least willing to allow me to think, that I might find the Italian restaurant by going around the corner; and so he has implicated that I might find the Italian restaurant by going around the corner.

In a situation involving a flouting-as in the case of the letter written by the university professor on behalf of his former student-the corresponding argument would differ from the one above only in that it would contain words to the effect that even though the professor had clearly flouted the first submaxim of quantity, he might, nevertheless, be presumed to be observing the Cooperative Principle. ${ }^{5}$

In light of what has been said, it is to be hoped that the implicatures required by

Principia 14(3): 405-419 (2010). 
the Implicature Theory will be shown to be cancelable and also susceptible to calculation by the use of arguments that mirror the one presented above. Since Schiffer (1987) interestingly argues that Salmon faces considerable problems in connection with calculability, I shall be content to present in due course my own argument to the effect that the Implicature Theory cannot be construed along Gricean lines, because the 'impartations' required by Salmon's theory are not always cancelable.

\section{V}

We are now in a position to present some of the insights offered by Implicature theorists and to cast a sympathetic look at their efforts. The implicatures they need would presumably be inferred by addressees of attitude ascriptions operating on the undeclared assumption that the ascriber is complying with a set of relevant maxims. In the case of floutings, the implicatures could still go through as long as the addressees-or, more generally, the audience-take the ascriber to be cooperating in a broader sense, in spite of the obvious violation of some particular maxim.

A fully cooperative ascriber would be expected to be faithful, whenever this is both possible and relevant, to something like the inner content of the attitudes. ${ }^{6}$ In other words, he would be expected to put himself in the shoes of the subjects of the attitudes and present the ascription in a way that is accountable to what the persons to whom the attitudes are ascribed would themselves be prepared to accept as reflecting their own attitudinal states. As Recanati points out, this could be expressed by means of what he calls the maxim of faithfulness-which is, perhaps, related to Grice's first submaxim of quantity, as, other things being equal, a faithful report is more informative than a non-faithful one.

\section{Maxim of faithfulness}

In reporting a belief about an object, and especially in referring to that object, use an expression which the believer himself would use (insofar as differences of language or context permit), or at least, try to be faithful to the believer's own point of view, unless there are reasons not to do so. (Recanati 1993, p.333)

Although they did not explicitly use the Gricean terminology and, thus, came short of explicitly formulating maxims, some Implicature theorists laid stress on additional communicative obligations incurred by attitude ascribers: 'Other things being equal, it is best to use the referring expression most likely to secure successful identification by the person(s) to whom the communication is addressed', 'Other things being equal, when using a descriptive referring expression, it is best to use the one that is most apposite to the topic of discourse"7 (Urmson 1968, pp.116-17); 'Assume that people [to whom the attitudes are ascribed] are cognitively coherent' (Barwise \& Perry 1983, p.258). ${ }^{8}$

Principia 14(3): 405-419 (2010). 
Although incomplete, the above list with some of the maxims proposed by the authors mentioned should be enough to get us going. Thus, if an utterance of 'Smith believes that Cicero was an orator' is produced, the argument justifying the implicature-based on the assumption that the ascriber is complying with the maxim of faithfulness - that Smith would assent to the sentence 'Cicero was an orator' might appropriately mirror the sort of argument Grice had in mind. It could go like this:

He has said that Smith believes that Cicero was an orator; there is no reason to believe that he is not observing the maxims and, specifically, the maxim of faithfulness; he could not be doing this unless he thought that Smith would assent to the sentence 'Cicero was an orator'; he knows (and knows that I know that he knows) that the supposition that he thinks that Smith would assent to the sentence 'Cicero was an orator' is required; he has done nothing to stop me thinking that Smith would assent to the sentence 'Cicero was an orator'; he intends me to think, or is at least willing to allow me to think, that Smith would assent to the sentence 'Cicero was an orator'; and so he has implicated that Smith would assent to the sentence 'Cicero was an orator'.

Predictably, the above implicature is such as to be liable to be explicitly cancelled by the person who said 'Smith believes that Cicero was an orator'. In the following passage, Barwise and Perry show how the implicature supported by the argument above could be canceled even before it has the chance of being generated:

Some arguments for referential opacity seem based on a confusion between conversational implicatures and semantic entailments. Thus we think that "Smith believes Cicero was an orator" does not imply, but at most suggests, that Smith would check "Cicero was an orator true". The suggestion is clearly cancelable: "Smith believes that Cicero was an orator, but only knows to call him 'Tully" (Barwise \& Perry 1981, p.374).

And, just as in some of Grice's examples, implicatures to the effect that the subject of a belief ascription would assent to the sentence contained in the 'that'- clause of an embedding ascription can also be prevented from arising-with no need of explicit cancellation-by particular circumstances surrounding the utterance. This is especially true in cases where the maxim of faithfulness is overridden by other maxims, observance to which may be of greater importance in particular cases. Thus, confronted with an utterance of 'Columbus thought that Cuba was in the Indies', we would not take it to implicate that Columbus would give his assent to (the Spanish translation of) the sentence 'Cuba is in the Indies', at a time when this country had not come into being. Yet, if we credit the historical record with sufficient accuracy, we would naturally take the above ascription to be true even if Columbus employed some other referring expression while talking about the island we now refer to as 'Cuba'. If, after conducting some historical inquiry into the way Columbus himself 
referred to Cuba, the ascriber had used his findings to replace the name 'Cuba' with some name actually used by Columbus, he would have failed to provide his audience with an ascription it could make any sense of. The maxim enjoining ascribers to secure successful identification of the referent of the name used in the embedded 'that'-clause overrides the maxim enjoining faithfulness and leads the audience to take the ascription to mean something like 'Concerning the island now known as 'Cuba', Columbus thought that it was in the Indies', where 'Cuba' has a transparent reading. Similar considerations would apply to an example provided by Recanati: 'John believes that the wealthy Cicero was poor'. On the assumption that people are for the most part logically consistent, the above ascription would be taken to mean 'Concerning the wealthy Cicero, John believes that he was poor', with 'the wealthy Cicero' also having a transparent reading. ${ }^{9}$ So far, all would seem to be going well for the supporters of the Implicature Theory. The Gricean apparatus appears to have some convincing applications in the domain of the attitudes. However, it would be premature to wholeheartedly endorse the Implicature Theory on the basis of such a limited diet of examples.

\section{VI}

When we consider the examples presented in the previous section, it is clear that the ascriber intended the ascriptions to take a de re reading. In 'Columbus thought that Cuba was in the Indies' and in 'John believes that the wealthy Cicero was poor', context itself ensures that the ascription was intended to have a de re reading. And even in the 'Smith believes that Cicero was an orator' case, the cancellation clause makes it clear that the ascriber intended his ascription to be interpreted de re, and that he was well aware of a significant difference between the semantic content of the proposition he took himself to be expressing and a collateral proposition, namely 'Smith would assent to the sentence "Cicero was an orator", which, he figured, risked being conversationally implicated by an utterance of 'Smith believes that Cicero was an orator'. In fact, the whole point of actually going about the business of canceling an implicature seems to rest on the conscious accessibility to the difference between the proposition one intends to express with an utterance of some sentence and the proposition or propositions that may be additionally conveyed.

But I hope to show now that this does not provide the Implicature Theorist with all that he needs. Let us suppose that both Jones and Smith are unaware of the fact that Cicero was Tully. Let us suppose further that Smith believes that Tully was an orator and that Cicero was a general. After a hurried and unfocused conversation about ancient Roman history with Smith, Jones forms the opinion that Smith believes that Tully was a general and that Cicero was an orator. Later, Jones goes on to say to Robinson: 'Smith believes that Cicero was an orator'. Having heard about Jones's

Principia 14(3): 405-419 (2010). 
incorrect statement, Smith sets him right by telling him that he does not believe that Cicero was an orator. Naturally enough, Jones concludes that his ascription was false. Not knowing that Cicero was Tully, Jones will most definitely not think-on the grounds that Smith believes that Tully was an orator and Tully was Cicero-that his was a true but misleading ascription. Now, the Implicature Theorist will have us believe that the ascription was indeed true but misleading, even though the ascriber himself takes it to have asserted-and not merely implicated-a plain falsehood. This shows that, in some cases, the Implicature Theory requires that those who engage in reporting the propositional attitudes of others have no conscious access to the semantic content of their own ascriptions. But, of course, this being the case, the ascriber would be in no position to cancel the alleged implicature.

For ascribers who find themselves in the same situation as Jones, it is not in the least clear, at an intuitive and pre-theoretical level, that there is an important difference between what they see as the semantic content encoded by their ascriptions and the implicature they are supposed to convey. Yet, in all the cases we have seen before there is a fair degree of pre-theoretical access to this sort of difference.

Now, it is no doubt true to say that Grice himself intended his theory of conversational implicature to cover cases in which speakers are not aware of any difference between the actual semantic content encoded by a sentence and an implicature that an utterance of the sentence may generate. The English connective 'and', in its temporal uses, provides us with the classical example of this sort of situation. If Liz got pregnant and subsequently married Jack, speakers would normally take the sentence 'Liz married Jack and got pregnant' to assert a falsehood. Still, it might be argued that 'Liz married Jack and got pregnant' is just as true as 'Liz got pregnant and married Jack', since, in either case, both conjuncts are true. One might maintain, by appealing to Grice's theory that 'and' has no special temporal sense that could be rendered explicit by having 'and' be replaced by 'and then'. The sentence 'Liz married Jack and got pregnant', though strictly true, is ordinarily considered to be false, because it is natural to assume that the person who uttered it, having no reason to violate the maxim enjoining orderliness, is presenting the events in the order in which he takes them to have occurred - an order that, as it turns out, is not true to the facts of the case. Thus employed, the notion of implicature seems to make it unnecessary for philosophers to take the connective 'and' to be semantically ambiguous as between its temporal and non-temporal uses. ${ }^{10}$ Thus, the supporters of the Implicature Theory would seem to be justified in saying that in at least some of the cases on which conversational implicatures have been brought to bear most speakers are not pre-theoretically aware of very real differences between the semantic content of their sentences and the sentences' pragmatic accompaniments. ${ }^{11}$ Accordingly, it might be argued that if a semantically and logically knowledgeable speaker-one, say, who knew that 'and' has no special temporal meaning over and above its truth-

Principia 14(3): 405-419 (2010). 
conditional meaning - went on to actually utter the sentence 'Liz married Jack and got pregnant', knowing all too well that Liz got pregnant before she married Jack, he would be in a position to cancel the predictable implicature carried by his utterance, namely that Liz married Jack before she got pregnant. The speaker's access to the semantic content of his sentence, in such cases, would be solely a matter of his acquiring a sufficient amount of philosophical sophistication. Interestingly, no amount of philosophical sophistication would solve the problem of accessibility in Jones's reports about Smith's beliefs. Even if Jones were a supporter of the Implicature Theory, his philosophical knowledge alone will not make him aware of the fact that 'Smith believes that Cicero was an orator' is a true but misleading sentence. He would also need to know that Cicero was Tully. But, of course, there is no guarantee that he will ever get to know that. As a matter of empirical fact, one can never rule out the possibility that the proper names in one's idiolect refer to things or persons which can also be referred to by other proper names that one is, and will remain, entirely unaware of.

This leaves us with an interesting situation: one of the distinguishing features of the implicatures Grice had in mind is their cancelability. A speaker's ability to cancel the implicatures generated by the sentences he utters seems to depend on a more or less sophisticated awareness of the difference between the semantic content of his sentences and the implicature or implicatures theirs utterance can generate. But in the case of attitude ascriptions, an all-round ability to cancel misleading implicatures would require nothing short of omniscience, or a God's eye view.

This makes it look as though the Gricean theoretical framework cannot serve the Implicature theorist, as one of the main features attending the generation of conversational implicatures, namely cancelability, may be shown not to be fully applicable to the Implicature Theory.

\section{References}

Barwise, J. \& Perry, J. 1981. Semantic Innocence and Uncompromising Situations. In: A. P. Martinich (ed.) (1990) The Philosophy of Language. Oxford: Oxford University Press, pp. 369-81.

. 1983. Situations and Attitudes. Cambridge, Mass: MIT Press/Bradford Books. Grice, P. 1989. Studies in the Way of Words. Cambridge, Mass: Harvard University Press. Levinson, S. C. 1983. Pragmatics. Cambridge: Cambridge University Press.

McKay, T. 1981. On Proper Names in Belief Ascription. Philosophical Studies 39: 287-303. Recanati, F. 1993. Direct Reference. Oxford: Blackwell Publishers.

Salmon, N. 1986. Frege's Puzzle. Atascadero, California: Ridgeview Publishing Company. Schiffer, S. 1987. The 'Fido'-Fido Theory of Belief. Philosophical Perspectives 1: 455-80.

Soames, S. 1987. Direct Reference, Propositional Attitudes, and Semantic Content. Philosophical Topics 15: 44-87.

Principia 14(3): 405-419 (2010). 
Urmson, J. O. 1968. Criteria of Intensionality. Aristotelian Society Proceedings, Supplementary Volume, 42: 107-22.

Wettstein, H. K. 2004. The Magic Prism: an Essay in the Philosophy of Language. Oxford: Oxford University Press.

\author{
RODRIGO JUNGMANN \\ Centro de Educação e Ciências Humanas \\ Universidade Federal de Sergipe \\ Cidade Universitária Prof. José Aloísio de Campos \\ Jardim Rosa Elze \\ 49100-000 São Cristóvão-SE \\ BRASIL \\ rodrigo_jungmann@yahoo.com.br
}

Resumo. Várias tentativas foram feitas pelos teóricos da referência direta para acomodar o dado intuitivo da opacidade referencial— a não ocorrência de substituição mútua salva veritate de nomes próprios co-referenciais nas orações subordinadas, precedidas por 'que', nas orações em que se atribuem atitudes proposicionais. A teoria defendida por Nathan Salmon, em seu livro de 1986 Frege's Puzzle, é provavelmente a versão mais bem elaborada daquilo a que adiante nos referimos como 'a Teoria Implicativa'. Salmon sustenta que a opacidade referencial é uma ilusão decorrente de nossa incapacidade de distinguir o conteúdo semântico de atribuições de crenças das suas 'partilhas pragmáticas', como Salmon as chama. Lamentavelmente, seu trabalho deixa de todo misterioso o mecanismo rotineiro de produção de tais partilhas pragmáticas. Salmon limita-se a sugerir vagamente que estão envolvidas implicaturas conversacionais griceanas. Minha tese central neste artigo é a de que Salmon está equivocado, visto que as partilhas pragmáticas necessárias à sua teoria não satisfazem o critério de cancelabilidade, o que deveria ocorrer sempre que estamos às voltas com uma genuína implicatura conversacional. O argumento apresentado, até onde o saibamos, é inteiramente original.

Palavras-chave: Atitudes proposicionais, cancelabilidade, implicaturas conversacionais, teoria implicativa.

\title{
Notes
}

1 'What is said' figures as a technical term in Grice's writings, standing for the truth-conditional content of expressions. Sometimes, 'what is said', in this sense, fails to capture the full conventional content of one's utterances. Thus, for Grice, the sentences 'Joe is a philosopher, and he is rich' and 'Joe is a philosopher, but he is rich' do not differ at the level of 'what is said', even though the use of but carries the conventional, as opposed to conversational, implicature that what is expressed by the second conjunct is not normally expected to be found alongside with what is expressed by the first conjunct. We need not further concern ourselves with conventional implicatures here.

${ }^{2}$ Slightly adapted from Grice 1989.

Principia 14(3): 405-419 (2010). 
3 These inferences are based on the remarkable robustness of the assumption of co-operation: if someone drastically and dramatically deviates from maxim-type behavior, then his utterances are still read as "underlyingly co-operative if this is at all possible" (Levinson 1983, p.109).

${ }^{4}$ Calculability, as a feature, is only implicitly referred to by Grice in own list on pp.39-40 (Grice 1989).

${ }^{5}$ Grice gives us a general (and slightly less wordy) version of arguments of this sort. (Grice 1989, p.31)

${ }^{6}$ Talk about inner content is tricky because it might be taken to suggest that the subject of a given attitude consciously entertains it in every case. But this construal of the attitudes is liable to produce unwelcome results. Thus, one might conceivably go on to deny that the ancients believed that Hesperus was Hesperus, on the grounds that, not being interested in logic or mathematics, most of them would never consciously entertain a statement of selfidentity. But for all that, they would assuredly give their assent to (a version in their own languages of) the sentence 'Hesperus is Hesperus'. So, we can avoid unnecessary problems by connecting belief with assent, using some version of the disquotational principle. Salmon himself treats de dicto attitudes along these lines.

${ }^{7}$ A possibility not considered by Urmson is that this particular injunction would perhaps also apply to the case of proper names, even though they lack a descriptive content that might (or might not) be of relevance to the topic of some on-going communicative event. The ascription 'Robert thinks that Lewis Carroll was a fantastic story-teller' would normally be preferable to the ascription 'Robert thinks that Charles Dogson was a fantastic storyteller'. Analogously, the ascription 'Lou thinks that Charles Dogson was a fine logician' would normally be preferable to 'Lou thinks that Lewis Carroll was a fine logician'. And this is so because the man in question is usually referred to as 'Lewis Carroll' in his capacity as a storyteller and as 'Charles Dogson' in his capacity as a logician.

${ }^{8}$ Urmson's maxims are perhaps related to Grice's maxim of Relevance. In particular, an ascription containing a proper name whose bearer cannot be identified by the audience fails to meet the communicative needs of those for whom it is intended. Barwise and Perry's maxim is harder to pin down.

9 These, of course, are cases of de re, as opposed to de dicto, attitude ascriptions.

${ }^{10}$ More generally, Grice maintained, on grounds of theoretical economy, that a pragmatic explanation for what looks like an apparent ambiguity in the use of a word is always preferable if it is at all possible. It is only as a last resort that one should go on to introduce a genuine semantic ambiguity-when no pragmatic account is available. That is the substance of what he called 'Modified Occam's Razor': Senses are not to be multiplied beyond necessity. (Grice 1989, p.47)

11 This is not to say that this move would be problem-free. As noted by Recanati (1993) and Wettstein (2004), in trying to boost their case by appealing to the alleged intuitive indistinguishability between semantically encoded and pragmatically conveyed information in the cases involving 'and' in its temporal uses, the Implicature theorist still faces the problem that the way Grice deals with this matter is by no means obviously right and might as well turn out to be wrong.

Principia 14(3): 405-419 (2010). 